\title{
when there are three
}

\author{
Trish Salah
}

\section{Quand ils sont trois}

Le narrateur-narratrice de Trish Salah dans "Quand ils sont trois» explore une subjectivitéet une sexualité liminaires. $D^{\prime}$ un mouvement qui à la fois défie les définitions étroites de «la femme» ou de «l'écriture féminine» et qui reconnaît l'expérience des femmes qui vivent dans un régime où l'on ne prend pas en considération leur différence sexuelle, illelle demande "qui écrit à partir d'une identité féminine et quel corps la détermine?" Repoussant les frontières reconnues du corps convenablement sexuéet d'un objet de désir "approprié», illelle rappelle que «selon le cadre choisi, on peut toujours couper certaine parties du corps et en laisser voir certaines autres». Encesens, "Quand ils sont trois" non seulement déstabilise l'équation binaire homme/femme, mais résiste à la négation de la différence sur laquelle s'appuie la culture dominante pour protéger ou renforcer une seule représentation et une seule pratique de la sexualité et du sexuel.

if i called you "darling" you would know all words are laden what's next? you might ask, roses? well, $i^{\prime} m$ in the grip of something you won't like \& i might call you (\& you as a prelude to stealing you away the delusion i could call (that you must answer must be symptomatic of what? my rapture in proximity? my lack of ego boundaries?

the other night, we three (i thought we were three the perfect revolutionary couple

poised for radical intervention, engaged art and hot sex 
well, my mistake, and thank you ( \& you

\section{for your protests}

because i was caught up in my own narrative, careening towards your thighs, your lips \& yours, white tusks shining

like knights on white chargers off to slay sexism, you know, though progressive non-possessive, wet and wild, truly liberatory

my dispute with penetration

could hardly be called chivalrous ( or disinterested) after all after the demo, you're to love me, need me, fuck me,

right?

nothing will,

\& if this poem doesn't do it, nothing will)

and anyway what's

one more cock

or less (unless)

donning these fake names in crimson

casting seduction as sedition

like Cixous' seamed stockings

i manage to beg, ask, force - the question?

who is writing in the feminine on whose body

whose cheesy equation of the feminine

with desire

is giving, getting

off here

and who slips

this is between you and who and me, just the three of us

who will trace, task, turn whose bodies for whose pleasure?

who's dumping whom?

or equally,

who says we can't make a home of pain for us all?

who says,

ain't that romantic?

you \& you, ever practical:

we've had enough of mutilation from our enemies, thanks, don't really need it from our friends why don't you go ironically venerate Madonna 
or masturbate in theory or

rather be painting a girl friend's toenails or my bathroom door, editing a zine or my self

but, yours in struggle

$$
\text { us (you (\& you)) }
$$

but

wait, wait! does this mean we can't even do genderfuck sometime

don birkenstock drag nostalgic

with linked arms so earnestly

handsome

march into the future?)

okay who's pushing now-

you two take it

you have your love,

$i^{\prime} m$ stuck, stupid in dustmotes

in the fever of light, in this unfinished poem

lodged in my spine, shivering and wanting you \& you

to efface myself

to say

the poem wants

to emerge in a body of love

to be dispersed

s/he's wearing her hair the way nostalgia does

mirrors, tucked behind ears,

under reversed baseball cap $\mathrm{s} /$ he boundlessly

collapses in to you, these touches,

your in)difference

more than s/ he could hope for

given the shape s/he left you in

as in thirsts, as in ghosts, as in as it gets

(and out of 
when there are three $\cdot 75$

all her-enveloping frictions

touches of, the very inside)

never has the hystery of this body been so un/clearly

a case of his story (that old saw)

going madly after hers

après hors

$$
\begin{aligned}
& \text { this in seme(s) less } \\
& \text { in sides taken, turned } \\
& \text { out of, or, }
\end{aligned}
$$

after

boundless

compared to

you're so big, how can s/he come to

(be

only this body

hysterical and less,

reliable?

some skin's out

in any frame some skin is in

memory snapshots exclusive clubs

membershipascertained

at press of skin

the condensation of self

is this realization of body

an inhabitation of desire?

(the in s/he needs

$$
\text { after breaking up }
$$

(some wind shield

some bloody fist)

on concrete

memory of you/her

confounded obliquely

embers raw lips

lapsing these now girl kisses

s/he says:

the new girl is no

thing to me

no girl now not like you no way no how not ever 
maybe it's just:

"the unconscious oedipus complex takes the form of a $\mathrm{k} / \mathrm{not}^{\text {" }}$

a can $/$ not

and you cut it

said ballsy:

cut it out

leading hir to decides / he could not find you and now i'm not too cordial as i cave on your demands

but before

your words "how

like a boy",

hang there unspoken

unspeak me

like a boy cannot be spoken

lips close about - uncut my tits, my clit,

unfrag me, unslice through

my womanly body

us like children hungering

me all wet gushing

pussy mess talk

what kinda

pussy must talk "me"

kiss and teething tongue seething

childtalk tied

you toss me

like a boy

out the window, into the ruins

moving on to your next sweet, love

unkiss me unkill me

why don't you

and how dare

you treat me

like a boy

horsexe/ whore sexed

- hardly a fit subject for desire

speaking the whole story of a sex $(\mathrm{k})$ not spoken

/hors plaisir/our pleasures were telling

the (h)our of the other us, 
fragments of three sliced from a crowd and piled on top of,

$\mathrm{s} /$ he's possessive still

scrawling our game plans

on the memory of the back of a napkin

balled and tossed in a dust bin:

in order to go awry you must confide in strangers

desire strangers' desires

hide the flicked tongue like a pimp

riding silvery sloped in humped backs

gain their trust

you may say "that most repulsive hysteric" but $s$ / he's getting used to that, anyway spent a long time rehearsing this little sign play, no supplement to your absence, dear-

your body gifted elsewhere to a straighter talkin' straighter shootin' boy

funny you're not here to hear

funny to think of more innocent endings:

that night in the bistro

the possibility of another route to love

opened with your words:

not so like a boy now

how did you read my fidgitting blush

arms curled one round one round small of back

straightjacket style and rocking

fragile, never more

sorry for my part in making

acceptable that cut of 3 ,

2,

sorry i cut you

out

up we all drift,

now you say 
you cannot hitch here

your voice is

gone

along these roads

gone

is what you were before $\mathrm{i}$ left

following always and racing

coming after

s/he's come undone

alone on the road

with a stranger

half frozen

to myself

leaving you.

taught me

you can't hitch in to love

love is closed

like a sign

saying "Closed"

i knocking against it all night long

wanting in

mouthing all the right words:

your can't is loose

i'm loose in it

your incantations

lost

your love hits hard on the road

i'm splayed upon

writing

open

s/he sees

why you didn't want her

as difference re)cedes

our ground moves,

her(e horizon 